Original Paper

\title{
Upaya Meningkatkan Kemampuan dan Keterampilan Guru Binaan Di SMA Lombok Tengah dalam Menerapkan Model Pembelajaran Cooperative learning Berbantuan Bimbingan Supervisi Akademik Pengawas
}

\author{
Bambang Nurcahyono ${ }^{1^{*}}$ \\ ${ }^{1}$ Dinas Pendidikan dan Kebudayaan UPTD. Layanan Dikmen \& PK-PLK Lombok Tengah.
}

*Corresponding Author:

Bambang Nurcahyono, Dinas

Pendidikan dan Kebudayaan UPTD.

Layanan Dikmen \& PK-PLK Lombok

Tengah, Indonesia;

Email:

nurcahyonobambang4@gmail.com

\begin{abstract}
Abstrak: Penelitian tindakan ini bertujuan mengetahui upaya meningkatkan kemampuan dan keterampilan guru binaan di SMA Lombok Tengah dalam menerapkan model pembelajaran cooperative learning berbantuan bimbingan supervisi akademik pengawas tahun pelajaran 2017-2018. Jenis penelitian ini adalah penelitian tindakan kepengawasan (PTKp) yang dilakukan dalam tiga siklus yang masing-masing siklusnya terdiri dari tahap (1) perencanaan, (2) pelaksanaan tindakan perbaikan, (3) observasi, dan (4) refleksi. Hasil penelitian adanya peningkatan pemahaman guru binaan tentang pendekatan model pembelajaran cooperative learning sekitar $28 \%$, adanya peningkatan keterampilan guru binaan dalam pembuatan rencana pembelajaran. Skor pencapaian nilai RPP pada siklus 3 meningkat dari 79,42 menjadi 91,37, dan adanya peningkatan aktivitas siswa dalam kegiatan belajar mengajar yang cukup berarti. Penelitian tindakan kepengawasan dapat disimpulkan bahwa berbantuan bimbingan supervisi akademik Pengawas Sekolah memiliki efektif dalam: a) meningkatkan pemahaman guru binaan dalam menerapkan model pembelajaran cooperative learning; b) meningkatkan keterampilan guru binaan dalam menerapkan model pembelajaran cooperative learning.
\end{abstract}

Kata kunci: Kemampuan, Keterampilan, Model Pembelajaran Cooperative Learning, Supervisi Akademik.

\section{Pendahuluan}

Diberlakukannya Peraturan Menteri Pendidikan Nasional No. 18 Tahun 2007 tentang Sertifikasi Guru, mewajibkan guru untuk memiliki sertifikat pendidik dalam jabatan melalui ujian sertifikasi. Usman (2007) menyatakan bahwa guru merupakan jabatan atau profesi yang memerlukan kompetensi khusus sebagai guru. Salah satu kompetensi yang dituntut adalah kompetensi pedagogik, dari merencanakan pembelajaran, melaksanakan pembelajaran, melaksanakan evaluasi dan analisis hasil evaluasi serta tindak lanjut.

Peraturan Menteri Pendidikan Nasional No. 22 Tahun 2016 tentang Standar Proses Pendidikan Dasar dan Menengah, merupakan acuan utama bagi guru binaan dalam melaksanakan proses pembelajaran. Peraturan Menteri Pendidikan dan Kebudayaan No. 22 tahun 2016 telah diundangkan pada tanggal 06 Juni 2016. Namun, hingga penelitian ini proses pembelajaran yang dilakukan guru binaan umumnya masih menggunakan skenario pembelajaran konvensional.

Pembuatan perangkat pembelajaran dan RPP adalah sangat penting. B. Uno (2006) menyebutkan bahwa perbaikan kualitas pembelajaran haruslah diawali dengan perbaikan desain pembelajaran. Pendekatan pembelajaran yang berpusat pada guru (teacher centre oriented) masih mendominasi dikalangan guru dalam melaksanakan kegiatan pembelajaran di kelas. Pada umumnya guru menggunakan strategi pembelajaran ekspositori dengan didominasi oleh metode ceramah, diskusi dan tanya jawab. Di dalam perangkat pembelajaran 
mereka jarang menggunakan strategi pembelajaran yang berpusat pada siswa (student centre oriented) dengan pendekatan discovery inkuiri. Sehingga pada kegiatan pembelajaran proses eksplorasi, elaborasi dan konfirmasi yang diharapkan muncul dari siswa tidak ada.

Selain itu, permasalahan yang sering ditemukan di sekolah adalah kurangnya persiapan guru dalam melakukan kegiatan pembelajaran yang masih monoton. Dari data yang ada, hanya sekitar $10 \%$ guru binaan yang memiliki perangkat pembelajaran yang lengkap, sementara yang lain masih belum memiliki. Jika ada, maka perangkat yang digunakan belum maksimal, bahkan kebanyakan perangkat yang ada bukan buatan sendiri. Sehingga dampak dari kegiatan proses belajar mengajar di kelas menjadi tidak menarik dan tidak memotivasi siswa. Permasalahan tersebut timbul dikarenakan minimnya pengetahuan dan kemampuan guru binaan dalam menyusun dan menggunakan perangkat pembelajaran sehingga kegiatan pembelajaran yang dilakukan tidak dipersiapkan dan dirancang dengan baik.

Berdasarkan hasil observasi kelas yang peneliti lakukan, hanya sebagian kecil guru binaan peneliti di SMA Lombok Tengah telah menerapkan pendekatan pembelajaran cooperative learning kreatif, efektif, dan menyenangkan (yang selanjutnya disebut model pembelajaran cooperative learning) di dalam kegiatan proses pembelajaran. Atas dasar kondisi tersebut peneliti sebagai pengawas Pembina mata pelajaran perlu untuk memberikan pemahaman dan keterampilan kepada guru binaan peneliti tentang penerapan model pembelajaran cooperative learning sebagai solusi dari kondisi di atas. Untuk mewujudkan kompetensi dan peran guru binaan dalam penerapan model pembelajaran cooperative learning perlu adanya upaya yang dilakukan baik oleh pengawas sekolah selaku pengawas pembina mata pelajaran. Bentuk upaya yang dapat dilakukan pengawas sekolah adalah melalui bimbingan dalam bentuk supervisi akademik, yang bertujuan untuk meningkatan keterampilan guru binaan dalam penerapan pembelajaran cooperative learning.

Pembelajaran cooperative learning adalah pembelajaran yang berfokus pada penggunaan kelompok kecil peserta didik untuk bekerja sama dalam memaksimalkan kondisi belajar untuk mencapai tujuan belajar (Nurhadi, 2004). Sementara Tambak (2017) menjelaskan bahwa penerapan metode cooperative learning dalam pembelajaran dimaksudkan untuk memperkuat pelajaran akademik setiap anggota kelompok dengan tujuan agar para peserta didik lebih berhasil dalam belajar dari pada belajar sendiri. Sebagai konsekuensinya untuk menjamin bahwa setiap peserta didik berhasil dan benar-benar bertanggung jawab terhadap pelajarannya sendiri maka setiap peserta didik harus diberi tanggung jawab secara individual untuk mengerjakan bagian tugasnya sendiri dan mengetahui apa yang telah ditargetkan dan yang harus dipelajari.

Berdasarkan uraian di atas, peneliti mencoba mengadakan penelitian tindakan kepengawas untuk mengetahui efektivitas kegiatan bimbingan melalui supervisi akademik yang dilakukan pengawas sekolah terhadap peningkatan keterampilan guru binaan dalam penerapan model pembelajaran cooperative learning. Dengan Penelitian Tindakan Kepengawasan ini diharapkan guru binaan dapat lebih melatih diri dan meningkatkan kemampuan pemahaman dan keterampilan tentang penerapan model pembelajaran cooperative learning secara maksimal, sehingga secara otomatis jika proses pembelajaran dirancang dengan baik, maka akan menciptakan suasana kelas yang kondusif dan dapat mencapai tujuan pembelajaran dengan mudah dan menyenangkan.

Tujuan penelitian tindakan kepengawasan ini adalah untuk mengetahui upaya meningkatkan kemampuan dan keterampilan guru binaan di SMA Lombok Tengah dalam menerapkan model pembelajaran cooperative learning berbantuan bimbingan supervisi akademik pengawas tahun pelajaran 2017-2018. Manfaat penelitian ini adalah sebagai berikut: 1) Dengan penerapan model pembelajaran cooperative learning, siswa akan meningkat semangat belajarnya sehingga memotivasi siswa untuk bertanya, menjawab, melakukan sesuatu tindakan yang berpola terstruktur, menemukan dan mengembangkan ideide baru; 2) Kompetensi menerapkan model pembelajaran Cooperative Learning akan memberi kemudahan dalam melaksanakan tugas mengajarnya, karena yang lebih aktif adalah siswa, dan guru hanya mengarahkan saja; 3) Hasil dari proses belajar mengajar yang efektif dan menyenangkan diharapkan dapat meningkatkan mutu pendidikan di sekolah. 


\section{Metode}

Penelitian ini merupakan penelitian kualitatif dengan pendekatan Penelitian Tindakan Sekolah yang dilakukan oleh pengawas sekolah sebagai peneliti. Dalam penelitian ini sebagai subjeknya adalah guru binaan peneliti di SMA Lombok Tengah tahun pelajaran 2017-2018 sebanyak 19 orang guru. Setting penelitian ini adalah: 1) Penelitian tindakan kepengawasan dilakukan pada guru binaan di SMA Lombok Tengah tahun pelajaran 2017-2018; 2) Guru binaan di SMA Lombok Tengah yang dijadikan sampel penelitian berjumlah 19 orang.

Rancangan Penelitian ini adalah: 1) Tindakan dilaksanakan dalam 3 siklus, meliputi perencanaan, tindakan, pengamatan, refleksi; 2) Kegiatan dilaksanakan dalam semester ganjil tahun pelajaran 2017-2018; 3) Lama penelitian PTKp dilaksanakan mulai tanggal 11 Setember 2017 s.d 30 Oktober 2017. Rancangan Penelitian Tindakan Kepengawasan (PTKp) menurut Kemmis dan Taggart (1992) dapat dilihat pada Gambar 1.

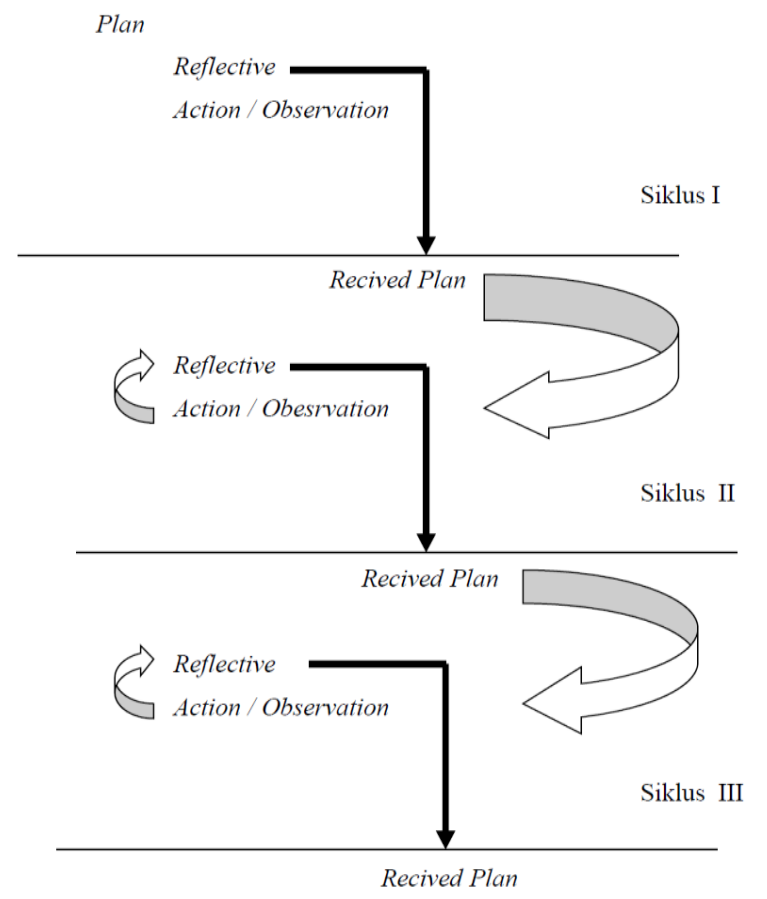

Gambar 1. Rancangan Penelitian Tindakan Kepengawasan

Penjelasan rancangan penelitian tindakan kepengawasan pada Gambar 1 adalah: 1) Rencana (Plan) adalah rencana tindakan apa yang dilakukan untuk memperbaiki, meningkatkan atau perubahan perilaku dan sikap sebagai solusi; 2) Tindakan (Action) adalah apa yang dilakukan oleh peneliti/pengawas sebagai upaya perbaikan, peningkatan atau perubahan yang diinginkan; 3) Observasi (Observation) adalah mengamati atas hasil atau dampak dari tindakan yang dilaksanakan atau dikenakan terhadap guru; 4) Refleksi (reflection) adalah peneliti mengkaji, melihat, dan mempertimbangkan atas hasil atau dampak dari tindakan dari pelbagai keriteria; 5) Revisi (recived plan) adalah berdasarkan dari hasil refleksi ini, peneliti melakukan revisi terhadap rencana awal.

Dalam penelitian tindakan kepengawasan ini variabel yang diteliti adalah peningkatan kinerja guru dalam melaksanakan pembelajaran yang efektif melalui supervisi klinis pengawas upaya meningkatkan mutu di SMA Lombok Tengah tahun pelajaran 2018-2019. Penelitian tindakan kepengawasan yang dilaksanakan dalam tiga siklus dianggap sudah berhasil apabila terjadi peningkatan kinerja guru dalam melaksanakan tugasnya apabila 85\% guru (sekolah yang diteliti) telah mencapai ketuntasan dengan nilai rata rata 75 . Jika peningkatan tersebut dapat dicapai pada tahap siklus 1 dan 2, maka siklus selanjutnya tidak dilaksanakan karena tindakan yang dilakukan sudah dinilai efektif sesuai dengan harapan dalam manajemen berbasis sekolah (MBS). Teknik analisis data dalam penelitian ini adalah: 1) Kuantitatif, Analisis ini digunakan untuk menghitung besarnya peningkatan kompetensi guru dalam melaksanakan pembelajaran yang efektif di sekolah dengan menggunakan prosentase (\%). 2) Kualitatif, teknik analisis ini digunakan untuk memberikan gambaran hasil penelitian secara; reduksi data, sajian deskriptif, dan penarikan simpulan.

Dalam Penelitian Tindakan Kepengawasan ini, rancangan tindakan yang dilakukan untuk meningkatkan kompetensi guru binaan dalam melaksanakan model pembelajaran cooperative learning berupa supervisi akademik yang diikuti seluruh guru binaan serta kegiatan bimbingan dalam praktek mengajar di kelas (khusus dilaksanakan untuk 19 orang guru yang menjadi subyek penelitian). Secara rinci tindakan yang akan dilaksanakan adalah sebagai berikut: 1) Mengadakan supervisi akademik pengembangan model pembelajaran cooperative learning yang diikuti guru binaan peneliti di SMA Lombok Tengah; 2) Membimbing guru binaan untuk 
membuat persiapan mengajar (RPP) berbasis pendekatan model pembelajaran cooperative learning; 3) Mengamati kegiatan guru binaan dalam melaksanakan kegiatan pembelajaran berbasis pendekatan model pembelajaran cooperative learningl 4) Mengadakan refleksi (diskusi antara peneliti dengan guru binaan yang diamati) tentang kelebihan dan kekurangan kegiatan pembelajaran berbasis pendekatan model pembelajaran cooperative learning yang telah dilaksanakan dan mencoba membuat formula untuk pelaksanaan siklus berikutnya.

\section{Hasil dan Pembahasan}

\section{Siklus I}

Kegiatan yang dilaksanakan dalam tahap ini adalah melaksanakan kegiatan bimbingan dalam bentuk supervisi akademik. Kegiatan ini dilaksanakan pada hari Selasa tanggal 19 September 2017. Pelaksanaan kegiatan ini diawali dengan pretes; dilanjutkan pemaparan materi dan diskusi; dan diakhir dengan post tes. Dalam kegiatan ini, pengawas sekolah sebagai peneliti bertindak sebagai narasumber dan dibantu oleh guru binaan yang telah mendapat bimbingan dalam bentuk supervisi akademik yang sama serta sudah menggunakannya dalam kegiatan pembelajaran di kelas. Guru binaan lain termasuk di dalamnya guru binaan yang dipilih menjadi subyek penelitian bertindak sebagai peserta supervisi akademik yang diwajibkan mengikuti serta mengerjakan tugas-tugas bimbingan dalam bentuk supervisi akademik. Kegiatan bimbingan dalam bentuk supervisi akademik ini juga dilaksanakan dalam dua bentuk kegiatan, yakni 1) pemaparan materi oleh nara sumber (pengawas sekolah dan guru binaan yang telah menguasai model pembelajaran cooperative learning); 2) tugas kelompok untuk menyusun RPP yang mengedepankan pendekatan model pembelajaran cooperative learning. Kegiatan pemaparan materi dilaksanakan selama 2 jam, sedangkan tugas kelompok untuk penyusunan RPP dilaksanakan selama 4 jam. Hasil penelitian pada Siklus I terdapat pada Tabel 1.
Tabel 1. Data hasil pengamatan aktivitas guru binaan dalam mengikuti bimbingan dalam bentuk supervise akademik pengembangan model pembelajaran cooperative learning

\begin{tabular}{llllll}
\hline No & Guru & $\begin{array}{l}\text { Keseriusan } \\
\text { mengikuti } \\
\text { bimbingan }\end{array}$ & $\begin{array}{l}\text { Kesediaan } \\
\text { bekerja } \\
\text { sama }\end{array}$ & $\begin{array}{l}\text { Keak } \\
\text {-tifan }\end{array}$ & $\begin{array}{l}\text { Jumlah } \\
\text { Nilai }\end{array}$ \\
\hline 1. & Guru 01 & 5 & 4 & 5 & 14 \\
2 & Guru 02 & 5 & 4 & 5 & 14 \\
3 & Guru 03 & 5 & 4 & 4 & 13 \\
4 & Guru 04 & 4 & 3 & 2 & 11 \\
5 & Guru 05 & 5 & 4 & 4 & 13 \\
6 & Guru 06 & 5 & 4 & 5 & 14 \\
7 & Guru 07 & 5 & 4 & 5 & 14 \\
8 & Guru 08 & 5 & 4 & 4 & 13 \\
9 & Guru 09 & 4 & 4 & 4 & 12 \\
10 & Guru 10 & 4 & 4 & 4 & 12 \\
11 & Guru 11 & 5 & 3 & 5 & 13 \\
12 & Guru 12 & 4 & 2 & 3 & 11 \\
13 & Guru 13 & 4 & 3 & 3 & 11 \\
14 & Guru 14 & 4 & 3 & 2 & 11 \\
15 & Guru 15 & 4 & 3 & 3 & 11 \\
16 & Guru 16 & 5 & 4 & 4 & 13 \\
17 & Guru 17 & 5 & 4 & 5 & 14 \\
18 & Guru 18 & 5 & 4 & 5 & 14 \\
19 & Guru 19 & 5 & 4 & 5 & 14 \\
\hline
\end{tabular}

Keterangan

Kriteria penilaian sebagai berikut:

$1=$ sangat tidak baik;

$2=$ tidak baik;

$3=$ kurang baik;

$4=$ baik;

$5=$ sangat baik

Pedoman Kriteria Skor:

Jumlah skor $0-3=$ Sangat tidak baik;

Jumlah skor $4-6=$ Tidak baik

Jumlah skor $7-9=$ Kurang baik;

Jumlah skor $11-12=$ Baik

Jumlah skor $13-15=$ Sangat baik

Berdasarkan pedoman kriteria skor dapat disimpulkan bahwa sebanyak 12 orang guru binaan atau sekitar $63 \%$ telah mengikuti supervisi akademik dengan aktivitas yang sangat baik. Hal tersebut dilihat dari aspek keseriusan mengikuti supervisi akademik dan mengerjakan tugas-tugas yang diberikan, kesediaan bekerjasama dan keaktifan. Dan sebanyak 7 orang guru binaan atau sekitar $37 \%$ telah mengikuti supervisi akademik dengan aktivitas yang baik. Dengan demikian tidak ada $(0 \%)$ guru binaan yang mengikuti supervisi akademik ini yang dapat dikatagorikan 
memiliki aktivitas yang kurang baik atau tidak baik.

Kegiatan yang dilakukan pada tahap ini adalah menganalisis hasil yang diperoleh dari pelaksanaan pre tes dan post tes serta data hasil observasi. Berdasarkan hasil pre tes dan post test terlihat adanya peningkatan tingkat pemahaman guru binaan peneliti dalam hal penerapan model pembelajaran cooperative learning. Hal ini dapat dilihat dari Tabel 2:

Tabel 2. Perbandingan hasil Pre Tes dan Post Tes kegiatan bimbingan dalam bentuk supervisi akademik pengembangan model pembelajaran cooperative learning guru binaan peneliti di SMA Lombok Tengah

\begin{tabular}{lllll}
\hline No. & Guru & Pre Tes & Post Tes & Selisih \\
\hline 1. & Guru 01 & 6 & 10 & 4 \\
2 & Guru 02 & 6 & 10 & 4 \\
3 & Guru 03 & 6 & 9 & 3 \\
4 & Guru 04 & 5 & 6 & 1 \\
5 & Guru 05 & 6 & 10 & 4 \\
6 & Guru 06 & 6 & 9 & 3 \\
7 & Guru 07 & 6 & 9 & 3 \\
8 & Guru 08 & 6 & 10 & 4 \\
9 & Guru 09 & 5 & 6 & 1 \\
10 & Guru 10 & 5 & 7 & 2 \\
11 & Guru 11 & 6 & 10 & 4 \\
12 & Guru 12 & 5 & 6 & 1 \\
13 & Guru 13 & 5 & 6 & 2 \\
14 & Guru 14 & 5 & 8 & 3 \\
15 & Guru 15 & 5 & 6 & 1 \\
16 & Guru 16 & 6 & 9 & 3 \\
17 & Guru 17 & 6 & 10 & 4 \\
18 & Guru 18 & 6 & 10 & 4 \\
19 & Guru 19 & 6 & 10 & 4 \\
Jumlah Nilai & 107 & 160 & 54 \\
Rata-rata & 5,63 & 8,42 & 2,84 \\
Prosentase & $56 \%$ & $84 \%$ & $28 \%$ \\
\hline
\end{tabular}

Berdasarkan data tersebut nilai rata-rata pre tes adalah 5,63 atau sekitar 57\% sedangkan rata-rata hasil post tes meningkat menjadi 8,42 atau $84 \%$. Hal ini menunjukkan ada peningkatan pemahaman guru binaan di SMA Lombok Tengah dengan model pembelajaran cooperative learning, yakni sekitar $27 \%$. Data ini ditunjang dengan hasil pengamatan (observasi) yang memperlihatkan bahwa seluruh guru binaan di SMA Lombok Tengah telah mengikuti bimbingan dalam bentuk supervisi akademik model pembelajaran cooperative learning dengan aktivitas yang baik, bahkan sebagian sangat baik.
Kenyataan di atas menunjukkan kegiatan Penelitian Tindakan Kepengawasan untuk meningkatkan pemahaman guru binaan di SMA Lombok Tengah dalam mengembangkan model pembelajaran cooperative learning telah tercapai dengan baik. Namun, ketercapaian untuk dapat meningkatkan keterampilan guru binaan di SMA Lombok Tengah dalam mengembangkan model pembelajaran cooperative learning belum dapat dinyatakan berhasil karena masih ada guru binaan belum mempraktekkan pemahaman mereka tentang model pembelajaran cooperative learning secara langsung di kelas. Atas dasar itulah maka dibutuhkan siklus berikutnya berupa bimbingan langsung praktek penerapan model pembelajaran cooperative learning di kelas.

\section{Siklus 2}

Kegiatan pelaksanaan tindakan yang dilaksanakan pada siklus 2 tanggal 2 Oktober 2017 ini adalah adalah: a) mengadakan diskusi dan memberi pendampingan bagi guru binaan untuk membuat persiapan mengajar atau Rencana Pelaksanaan Pembelajaran (RPP) yang akan digunakan pada siklus 2 ini; b) Memonitoring atau mensupervisi kegiatan pelaksanaan skenario pembelajaran yang telah disusun dan direncanakan sebelumnya. Kegiatan pengawas sekolah sebagai peneliti adalah mengamati jalannya proses pembelajaran dengan menggunakan instrumen, observasi, sementara kegiatan guru binaan melaksanakan kegiatan pembelajaran sesuai dengan rencana yang telah disusun sebelumnya. Dari hasil pengamatan praktik pembelajaran guru binaan di sekolah masing-masing diperoleh hasil seperti Tabel 3:

Tabel 3. Hasil Capaian supervisi praktik pembelajaran di kelas (Siklus II) setelah menerima kegiatan bimbingan

\begin{tabular}{lrlll}
\hline No & Guru & $\begin{array}{l}\text { Jumlah } \\
\text { Skor }\end{array}$ & Nilai & Keterangan \\
\hline 1 & Guru 01 & 10 & 91 & Sangat Baik \\
2 & Guru 02 & 10 & 91 & Sangat Baik \\
3 & Guru 03 & 8 & 73 & Cukup \\
4 & Guru 04 & 6 & 55 & Kurang \\
5 & Guru 05 & 9 & 82 & Baik \\
6 & Guru 06 & 9 & 82 & Baik \\
7 & Guru 07 & 5 & 45 & Kurang \\
8 & Guru 08 & 9 & 82 & Baik \\
9 & Guru 09 & 6 & 55 & Kurang \\
10 & Guru 10 & 6 & 55 & Kurang \\
11 & Guru 11 & 10 & 91 & Sangat Baik \\
\hline
\end{tabular}




\begin{tabular}{lrlll}
\hline No & Guru & $\begin{array}{l}\text { Jumlah } \\
\text { Skor }\end{array}$ & Nilai & Keterangan \\
\hline 12 & Guru 12 & 7 & 64 & Cukup \\
13 & Guru 13 & 6 & 55 & Kurang \\
14 & Guru 14 & 9 & 82 & Baik \\
15 & Guru 15 & 7 & 64 & Cukup \\
16 & Guru 16 & 9 & 82 & Baik \\
17 & Guru 17 & 10 & 91 & Sangat Baik \\
18 & Guru 18 & 10 & 91 & Sangat Baik \\
19 & Guru 19 & 10 & 91 & Sangat Baik \\
\hline
\end{tabular}

$\begin{array}{ll}\text { Keterangan: } & \\ 91-100 & =\text { Sangat Baik } \\ 78-90 & =\text { Baik } \\ 61-77 & =\text { Cukup } \\ 60< & =\text { Kurang }\end{array}$

Berdasarkan data tersebut capaian nilai sangat baik ada 6 orang guru atau sekitar 32\%, capaian nilai baik ada 5 orang guru atau sekitar $26 \%$, capaian nilai cukup dan kurang ada 8 orang guru atau sekitar $42 \%$. Hal ini menunjukkan ada peningkatan keterampilan guru binaan di SMA Lombok Tengah dalam mengembangkan model pembelajaran cooperative learning sebesar $58 \%$.

\section{Siklus 3}

Kegiatan pelaksanaan tindakan yang dilaksanakan pada siklus 3 tanggal 16-28 Oktober 2018 adalah mengadakan diskusi dan memberi pendampingan bagi guru binaan untuk merevisi persiapan mengajar atau Rencana Pelaksanaan Pembelajaran (RPP) yang telah digunakan pada siklus yang lalu atau sebelumnya. Hasil revisi, kemudian dijadikan RPP yang digunakan pada siklus ini (siklus 3). Selain itu, pengawas sekolah sebagai peneliti juga berperan untuk memonitoring atau mensupervisi kegiatan pelaksanaan skenario pembelajaran yang telah disusun dan direncanakan sebelumnya.

Dengan demikian kegiatan pengawas sekolah akan lebih fokus untuk mengamati jalannya proses pembelajaran dan aktivitas siswa selama mengikuti KBM dengan menggunakan instrumen observasi, sementara kegiatan guru binaan melaksanakan kegiatan pembelajaran sesuai dengan rencana yang telah disusun sebelumnya. Adapun materi, metode dan media pembelajaran yang telah dipersiapkan oleh guru binaan yang menjadi subyek penelitian untuk digunakan pada pertemuan di siklus 3 .

Berdasarkan data dari hasil penilaian RPP diperoleh data bahwa RPP yang dibuat oleh guru binaan yang menjadi subyek penelitian dapat dikatagorikan cukup baik dilihat dari unsur kejelasan tujuan, pemilihan dan pengorganisiran materi, kejelasan skenario, penggunaan metode dan alat evaluasi yang digunakan. Hal tersebut dapat dilihat pada Tabel 4:

Tabel 4. Rekapitulasi hasil penilaian RPP model cooperative learning pertemuan pada siklus II dan siklus 3

\begin{tabular}{llllll}
\hline \multirow{2}{*}{ No. } & \multirow{2}{*}{ Guru } & \multicolumn{2}{l}{ Siklus II } & \multicolumn{2}{l}{ Siklus III } \\
& & Skor & Nilai & Skor & Nilai \\
\hline 1. & Guru 01 & 73 & 97 & 73 & 97 \\
2. & Guru 02 & 73 & 97 & 73 & 97 \\
3. & Guru 03 & 73 & 97 & 73 & 97 \\
4. & Guru 04 & 50 & 67 & 67 & 89 \\
5. & Guru 05 & 66 & 88 & 70 & 93 \\
6. & Guru 06 & 62 & 83 & 67 & 89 \\
7. & Guru 07 & 61 & 81 & 69 & 92 \\
8. & Guru 08 & 55 & 73 & 67 & 89 \\
9. & Guru 09 & 55 & 73 & 58 & 77 \\
10. & Guru 10 & 54 & 72 & 70 & 93 \\
11 & Guru 11 & 64 & 85 & 71 & 95 \\
12 & Guru 12 & 55 & 73 & 57 & 76 \\
13 & Guru 13 & 53 & 71 & 66 & 88 \\
14 & Guru 14 & 64 & 85 & 67 & 89 \\
15 & Guru 15 & 57 & 76 & 65 & 87 \\
16 & Guru 16 & 73 & 97 & 73 & 97 \\
17 & Guru 17 & 73 & 97 & 73 & 97 \\
18 & Guru 18 & 73 & 97 & 73 & 97 \\
19 & Guru 19 & 73 & 97 & 73 & 97 \\
Jumlah & & 1509 & & 1736 \\
Rata-Rata & & 79.42 & & 91.37 \\
Persentase & & $79 \%$ & & $91 \%$ \\
\hline \multicolumn{1}{l}{ Keterangan: } & & & &
\end{tabular}

Keterangan:

$\begin{array}{ll}91-100 & =\text { Sangat Baik } \\ 78-90 & =\text { Baik } \\ 61-77 & =\text { Cukup } \\ 60< & =\text { Kurang }\end{array}$

Berdasarkan data pada tabel di atas dapat dinyatakan bahwa RPP yang telah dibuat guru binaan ada peningkatan nilai dari pertemuan 1 pada siklus II sebesar 79,42, kemudian diperbaiki di pertemuan 2 pada siklus 3 dengan nilai 91,37. Hal ini dibuktikan persen keberhasilan lebih dari nilai standar indikator keberhasilan, yaitu dari 79\% menjadi $91 \%$ (di atas nilai standar 85\%). Dengan demikian guru binaan sudah mampu merancang RPP yang mencerminkan model pembelajaran cooperative learning.

Selanjutnya terlihat dari praktek atau pelaksanaan pembelajaran yang dilaksanakan guru binaan cukup menggembirakan. Hal ini karena 
kegiatan pembelajaran yang dilakukan oleh 8 orang guru binaan yang menjadi subyek penelitian sudah memperlihatkan penerapan pendekatan model pembelajaran cooperative learning. Dari hasil pengamatan praktik pembelajaran guru binaan di sekolah masing-masing diperoleh data sebagai berikut:

Tabel 5. Hasil Capaian supervisi praktik pembelajaran di kelas (Siklus III) setelah menerima kegiatan bimbingan

\begin{tabular}{lllll}
\hline No & Guru & $\begin{array}{l}\text { Jumlah } \\
\text { Skor }\end{array}$ & Nilai & Keterangan \\
\hline 1 & Guru 01 & 9 & 82 & Baik \\
2 & Guru 02 & 9 & 82 & Baik \\
3 & Guru 03 & 9 & 82 & Baik \\
4 & Guru 04 & 9 & 73 & Cukup \\
5 & Guru 05 & 9 & 82 & Baik \\
6 & Guru 06 & 8 & 73 & Cukup \\
7 & Guru 07 & 8 & 82 & Baik \\
8 & Guru 08 & 9 & 82 & Baik \\
\hline
\end{tabular}

Keterangan:

91-100 = Sangat Baik

$78-90=$ Baik

61-77 = Cukup

$60<\quad=$ Kurang

Berdasarkan data di atas, terlihat bahwa pelaksanaan pembelajaran yang dilakukan 8 orang guru binaan (berkatagori cukup dan kurang) yang menjadi subyek penelitian, telah meningkat keterampilannya dalam mengembangkan model pembelajaran cooperatif learning, dengan demikian sudah 17 orang atau $90 \%$ (melebihi nilai indikator keberhasilan 85\%) guru binaan yang telah mencapai kriteria baik atau sangat baik. Dilihat dari keaktifan siswa selama pelaksanaan pembelajaran pada Siklus II dan Siklus III dapat dilihat pada tabel berikut:

Tabel 6. Data perbandingan hasil pengamatan aktivitas siswa dalam pelaksanaan pembelajaran pada Siklus II dan Siklus III

\begin{tabular}{llllll}
\multirow{2}{*}{ No. } & \multirow{2}{*}{ Guru } & \multicolumn{2}{l}{ Siklus II } & \multicolumn{2}{l}{ Siklus III } \\
& & Skor & Nilai & Skor & Nilai \\
\hline 1. & Guru 01 & 8 & 80 & 9 & 90 \\
2. & Guru 02 & 8 & 80 & 9 & 90 \\
3. & Guru 03 & 7 & 70 & 8 & 80 \\
4. & Guru 04 & 6 & 60 & 9 & 90 \\
5. & Guru 05 & 7 & 70 & 8 & 80 \\
6. & Guru 06 & 7 & 70 & 8 & 80 \\
7. & Guru 07 & 6 & 60 & 9 & 90 \\
8. & Guru 08 & 7 & 70 & 8 & 80 \\
9. & Guru 09 & 5 & 50 & 7 & 70 \\
10. & Guru 10 & 6 & 60 & 9 & 90 \\
\hline
\end{tabular}

\begin{tabular}{|c|c|c|c|c|c|}
\hline 11 & Guru 11 & 8 & 80 & 9 & 90 \\
\hline 12 & Guru 12 & 6 & 60 & 8 & 80 \\
\hline 13 & Guru 13 & 6 & 60 & 9 & 90 \\
\hline 14 & Guru 14 & 8 & 80 & 8 & 80 \\
\hline 15 & Guru 15 & 7 & 70 & 9 & 90 \\
\hline 16 & Guru 16 & 8 & 80 & 8 & 80 \\
\hline 17 & Guru 17 & 8 & 80 & 9 & 90 \\
\hline 18 & Guru 18 & 8 & 80 & 9 & 90 \\
\hline 19 & Guru 19 & 8 & 80 & 9 & 90 \\
\hline \multicolumn{3}{|c|}{ Jumlah } & \multicolumn{2}{|c|}{1340} & 1620 \\
\hline \multicolumn{3}{|c|}{ Rata-Rata } & \multicolumn{2}{|c|}{70.53} & 86.26 \\
\hline \multicolumn{3}{|c|}{ Persen (\%) } & \multicolumn{2}{|c|}{$71 \%$} & $85 \%$ \\
\hline
\end{tabular}

Keterangan:

91-100 = Sangat Baik

78-90 = Baik

61-77 = Cukup

$60<\quad=$ Kurang

Dilihat dari data hasil pengamatan aktivitas siswa diperoleh nilai rata-rata aktivitas siswa pada pertemuan 1 sebesar 70,53 belum memenuhi nilai standar 75 , sedangkan pada pertemuan 2 nilai aktivitas siswa mengalami kenaikan signifikan sebesar 85,26 melebihi nilai indikator keberhasilan 75,00 dan sedangkan nilai persentase pada pertemuan $171 \%$ naik pada pertemuan 2, yaitu $86 \%$ sehingga persentase keberhasilan telah memenuhi nilai standar indikator keberhasilan $85 \%$.

Hasil refleksi berupa kegiatan diskusi antara peneliti dan guru binaan diketahui bahwa adanya peningkatan nilai kompetensi guru binaan dan siswa tersebut disebabkan karena mereka (guru binaan yang menjadi subyek penelitian) telah menggunakan metode dan media pembelajaran yang lebih variatif. Ini menunjukkan bahwa metode dan media yang variatif ternyata dapat meningkatkan aktivitas siswa dalam belajar. Hal ini menunjukkan bahwa kegiatan Penelitian Tindakan Kepengawasan ini telah mencapai tujuan yang diharapkan.

\section{Kesimpulan}

Berdasarkan hasil pelaksanaan penelitian tindakan sekolah dapat disimpulkan: 1) bimbingan dalam bentuk supervisi akademik penerapan model pembelajaran cooperative learning telah menambah pemahaman dan keterampilan guru binaan dalam penerapan model pembelajaran cooperative learning dalam pembelajaran di kelas; 2) Kegiatan 
bimbingan dalam bentuk supervisi akademik lebih banyak memberikan tambahan pengetahuan bagi guru binaan tentang materi pembinaan itu sendiri dalam hal ini tentang pendekatan model pembelajaran cooperative learning, sedangkan peningkatan keterampilan guru binaan dalam penerapan model pembelajaran cooperative learning di kelas lebih banyak diperoleh melalui kegiatan bimbingan dalam praktek langsung; 3) Bimbingan dalam bentuk supervisi akademik yang dilakukan Pengawas sekolah memiliki efektivitas yang cukup tinggi untuk meningkatkan pemahaman keterampilan guru binaan di SMA Lombok Tengah dalam penerapan model pembelajaran cooperative learning.

\section{Saran}

Berdasarkan hasil penelitian di atas saran yang dapat disampaikan adalah: (1) Penerapan pendekatan Pembelajaran cooperative learning perlu terus ditingkatkan mengingat cukup signifikan dampak postitif penerapannya terhadap peningkatan proses dan hasil belajar siswa; (2) Guru binaan harus dapat mengenali dan menggunakan berbagai metode, strategi dan/atau model pembelajaran; sehingga mempunyai banyak pilihan untuk dapat menerapkan pendekatan model pembelajaran cooperative learning dalam kegaitan belajar mengajar; (3) Selain keterampilan memilih model pembelajaran, guru binaan yang professional juga hendaknya dapat memilih media yang tepat untuk menyampaikan materi pembelajaran. Oleh karena itu, guru binaan juga dituntut memliki kreativitas dan keterampilan memilih media pembelajaran yang tepat; (4) bimbingan supervisi akademik dalam bentuk penerapan model pembelajaran yang mengedapankan pendekatan model pembelajaran cooperative learning perlu terus diberikan terutama ole para pengawas pembina mata pelajaran para guru (baik kepada guru binaan maupun guru-guru di sekolah binaannya).

\section{Daftar Pustaka}

B. Uno, Hamzah. 2008. Teori Motivasi dan Pengukurannya, Jakarta : Bumi Aksara
Kemendikbud. 2016. Permendikbud Nomor 22 Tahun 2016 Tentang Standar Proses Pendidikan Dan Menengah. Jakarta: Kemendikbud

Kemmis, S \& Mc Taggart, R. 1992.The Action Research Planner. Australia: Deakin University Press.

Nurhadi. 2004. Kurikulum 2004; Pertanyaan dan Jawaban. Jakarta: Grasindo.

Peraturan Menteri Pendidikan Nasional Nomor 18 Tahun 2007 tentang Sertifikasi bagi Guru Dalam Jabatan.

Tambak, S. 2017. Metode Cooperative Learning Dalam Pembelajaran Pendidikan Agama Islam. Jurnal Al-Hikmah, 14(1).

Usman, N. 2007. Manajemen Peningkatan Kinerja Guru. Bandung: Mutiara Ilmu 